\title{
Guerreiro Ramos in the United States: his life through the lens of political exile
}

\author{
Diana de Groat Brown
}

Bard College, New York, USA

E-mail:dbrown@bard.edu 


\section{Abstract}

I explore Guerreiro Ramos's years of exile in the United States (1966-1982) asking how a leftist Brazilian intellectual of African descent dealt with the social and political climate of the U.S. during this period. I focus on two issues: his career at the University of Southern California's School of Public Administration, where he remained until his death; and his relationship as a Brazilian of color to the radical racial politics in the U.S. during this period. I argue that at USC, Guerreiro Ramos's pragmatism and ability to create success within adverse circumstances, learned during his career in Brazil, enabled him to do the same at USC - to turn the adversity of exile into similarly creative success. His brilliance and charisma as an intellectual and as a teacher won him admiration, respect, popularity and a secure academic career. His creativity and openness to new ideas enabled him to embrace the field of American sociology even as he continued to oppose American imperialism, and to bring sociology to the critique of American public administration. As to his relationship to American racial politics of this period, even in Brazil he had already moved away from his former engagement with racial issues, and this continued in the U.S. I speculate that his identity as an exotic foreigner protected him from experiencing directly the racial discrimination directed at African Americans. Finally, his exile heightened his sense of being an outsider, a 'parenthetical man' in Brazil as well as in the U.S.

Keywords: Guerreiro Ramos. Exile. Public Administration. Race.

\section{Resumo}

Neste artigo são explorados os anos de exílio de Guerreiro Ramos nos Estados Unidos (1966-1982), questionando como um intelectual esquerdista brasileiro, de ascendência africana, lidou com o clima social e político dos Estados Unidos nesse período. O foco está em duas questões: sua carreira na Escola de Administração Pública da University of Southern California (USC), onde ele permaneceu até sua morte, e sua relação, como um brasileiro de cor, com a política racial radical nos Estados Unidos nesse período. Argumenta-se que, na USC, o pragmatismo e a habilidade de Guerreiro Ramos de produzir sucesso em circunstâncias adversas, aprendidos durante sua carreira no Brasil, possibilitaram-lhe fazer o mesmo na USC - transformar a adversidade do exílio em um sucesso criativo equiparável. Seu brilho e carisma como intelectual e como professor granjearam-lhe admiração, respeito, popularidade e uma carreira acadêmica segura. Sua criatividade e abertura a novas ideias permitiram-lhe abraçar o campo da sociologia americana, mesmo quando continuava a se opor ao imperialismo americano e a trazer a sociologia para a crítica da administração pública americana. Quanto a sua relação com a política racial americana desse período, mesmo no Brasil, ele já havia se afastado do engajamento anterior com as questões raciais e isso continuou nos Estados Unidos. A especulação aqui é que sua identidade como um estrangeiro exótico o protegeu de sofrer, diretamente, a discriminação racial direcionada aos afro-americanos. Finalmente, seu exílio aumentou seu senso de ser um "de fora", um "homem entre parêntesis" tanto no Brasil como nos Estados Unidos.

Palavras-chave: Guerreiro Ramos. Exílio. Administração Pública, Raça. 


\section{Introduction}

Tn this paper I offer some reflections on Alberto Guerreiro Ramos's Lyears of exile in the U.S., from 1966 when he left Brazil, to 1982, when he died in California. I will focus on the social and political dimensions of his life in the US: the circumstances of his exile, how he dealt with them; his reception by his new colleagues and his own activities at the University of Southern California (USC); and his relationship as a Brazilian of color to the broader political environment in California and the U.S. in which he now lived.

I know very little about Guerreiro Ramos's own view of his life as an exile, since his plan to write a memoir was tragically interrupted by his death, and his personal archive was not accessible to me. My comments here are based on published accounts of their impressions furnished by those who knew him at USC, both Brazilians and Americans who were his colleagues and students, an interview he gave in Brazil in 1981, somewhat ambiguous in tone, and his daughter's book (Guerreiro Ramos, E. 2003), through whose pages we obtain brief glimpses of her father.

In reading the available literature two things have stood out for me as particularly striking. The first is Guerreiro Ramos's 's extraordinary degree of success in adapting to his new environment at USC; and the second is his reticence on issues of race, and the ambiguity of his remarks on his experience of being a Black Brazilian in the U.S., given the racial ferment and conflicts taking place in his new surroundings. I have chosen to focus on these issues in my discussion here. 


\section{Moving to the U.S.}

At the time of the military coup, on April 1, 1964, Guerreiro Ramos was serving as a federal deputy for the leftist party, the PTB, and was a close colleague and advisor to President João Goulart. He was in one of the first groups of politicians to be cassado, and lost his seat in Congress, his pension from the years during which he had worked at DASP, and faced threats to his academic position at the Escola Brasileira de Administração Pública (EBAP) at the Fundação Getúlio Vargas (FGV). Thus he faced the loss of his entire means of economic support for himself, his wife and 2 children. He remained at EBAP for the following two years. Then, in 1966, as the military government was pressuring the FGV to fire him, he left for the U.S with the offer of a one year position as a visiting professor at the School of Public Administration of the University of Southern California, in Los Angeles.

The circumstances of his hiring are important because they significantly eased the initial impact of his exile. In 1959, with funding from USAID, The School of Public Administration at the University of Southern California (USC) had established a convênio with Public Administration programs in four Brazilian cities, including EBAP in Rio. This led to an exchange of personnel and training between the two institutions, and in 1962-1963 an American USC team of four professors from the School of Public Administration was administering a technical assistance project at EBAP. Guerreiro Ramos was teaching there at this time, and Frank Sherwood, a professor of public Administration with a PhD in Political Science, and leader of the team, recounts that he became aware of him because he was always surrounded by students and was reportedly "by far the most popular professor at the school". He was curious to meet him, but a mutual friend refused to introduce them because Guerreiro Ramos was "ideologically [...] seen as far to the left" and the friend feared that a meeting between the two would result in an ideological confrontation in the polarized political situation of the time (Sherwood, 2010, p. 120).

When Sherwood returned to EBAP in 1964 after the coup, he was "shocked" to find that Guerreiro Ramos, having been removed 
from political office by a U.S. Government supported military coup, had been awarded a substantial portion of a Ford Foundation grant to the FGV by its president to support research on Public Administration in Brazil. He was to write a book on this subject. Sherwood could not believe that they had given the grant to someone the U.S. embassy identified as a communist (Sherwood, 2010, p. 121), "[...] who was regarded as an enemy of the U.S." (Sherwood, 2014, p. 181).

But when Sherwood returned in 1966, he was again astonished, this time to discover that in a single year, Guerreiro Ramos had researched, written and published the book, Administração e Estratégia do Desenvolvimento: Elementos de uma Sociologia Especial da Administração (FGV, 1966). Wilson Pizza Junior, his typist and student assistant for the project, describes the intensity of this process (Pizza, 2014). Sherwood marveled that "[...] in one year Ramos had done a prodigious amount of Brazil-centric research, had written a manuscript of several hundred pages, and had seen his effort through various stages to the production of a book, and gotten it published" (Sherwood, 2010, p. 121). After reading it, he declared: "it was certainly the best thing I had ever read on administrative reform in Brazil, and very possibly the best of the world's literature....The whole world needed to become aware of this unique scholarly resource" (Sherwood, 2010 , p. 122). The book was read and widely admired by the other USC professors on the technical team, and was crucial in convincing trustees at USC of his importance as a scholar, and of the advantages of hiring him as a Visiting Professor.

Thus Guerreiro Ramos arrived in Los Angeles, in July of 1966. An American doctoral student recalls meeting him at a dinner party the night he arrived, tired and haggard from the trip (Kirkhart, 2014, p. 191). From all accounts, he was traumatized and deeply saddened by having to leave his beloved Brazil, a national political career and prominence as a leading scholar. He was going to a country he had visited only once in 1961, as a Brazilian delegate to the UN General Assembly appointed by Goulart. The U.S. had been instrumental in the 1964 coup that led to his exile, and he deeply opposed its economic and political policies. Few people at the university knew who he was. 
And he brought with him an intellectual orientation toward the social sciences and Public Administration embedded in French and German thought which was quite foreign to the dominant American empirical tradition in the U.S.

In this situation, the convênio between EBAP and the School of Public Administration at USC, and the presence of American professors there who already knew Guerreiro Ramos and admired his work was crucial. They knew something of his world, his reputation and his circumstances: they had lived in Brazil, and read and spoke Portuguese. And several Brazilian students had come to USC to study at the undergraduate, Masters and PhD levels. They could ease his transition and speak to his talents. Thus from the very beginning he had colleagues who to some degree understood and shared in his Brazilian world. Throughout his time at USC these remained his closest colleagues and friends.

These contacts were also important because his arrival was viewed by many of his new American colleagues as very problematic. He had no doctorate, no one knew the extent of his fluency in English, and he was viewed as a political radical. How would he fare in a fairly small but ambitious Public Administration program at a rather conservative private American university? The University of Southern California had begun in 1880 as a small Methodist college serving mainly the local community (Sample, 2005). Its School of Public Administration, the next to oldest in the nation, had begun in 1929. By 1980 it was the largest and one of the best programs in the nation (Sherwood, 2010, p. 94). At the time of Guerreiro Ramos's arrival in 1966 it was in the middle of a drive to expand and gain recognition, and he himself came to figure importantly in this process.

The public record by USC administrators and colleagues at the School of Public Administration reads like a love affair: "Little did we anticipate that Ramos would take USC by storm... and there was no way we would let him go back to Brazil, even if he could have (Sherwood, 2010, p. 122). "He had a tremendous effect on students", especially on more intellectually alive students...Doctoral students were flocking to his classes and quoting him regularly." (Sherwood, 
2010, p. 123-124). He was "[...] a special capture for the School of Public Administration - I don't believe any other program in the country could boast a professor of similar breadth and perspective (Sherwood, 2010, p. 119).

He was quickly granted tenure, and "[...] the leftist leader at EBAP became the provocative, stimulating, liberal professor at a fairly conservative university [...]" (Sherwood, 2010, p. 123). Frank Sherwood remained his enthusiastic mentor, but he didn't seem to need any special treatment: the praises poured in, the students flocked to his classes, and he won the respect, admiration, and even the awe of his colleagues for the breadth of his knowledge of the European as well as American literature in the social sciences.

In 2010, when a celebratory volume commemorating the School of Public Administration's (now renamed the School of Policy, Planning and Development) more than 80 years of success (Clayton et al., 2010) Kim Nelson, its former dean, noted in his introduction to the volume that this school had now become "the premier institution of its kind in the nation" (Nelson, 2010, p. 12) and that he considered Alberto Guerreiro Ramos to be one of two faculty members who had contributed most to its success: "two faculty members who were 'transformative figures' in this process [...]" "transformative because of their influence on the trajectory of life in the school [...] Ramos through his powerful intellectual and substantive contributions" (Sherwood, 2010, p. 19). "Ramos appeared in the USC world as a powerful and singular intellectual presence, a deeply probing and cross-cultural conceptualizer of organizational life. Demanding of students, yet tender-hearted and empathetic, his influence soon became widespread [...]" (Sherwood, 2010, p. 20), in other academic departments as well as in the School of Public Administration.

It was clear that Guerreiro Ramos had adapted very successfully to life at USC. In Sherwood's words, he "[...] fitted in beautifully; it seemed as if he had always been with us" (Sherwood, 2014, p. 185). Initial worries were forgotten: he was fluent in English, though he spoke with a heavy Brazilian accent, and he did not engage in radical politics. Though he had been a leftist politician in Brazil, he had never 
supported violence; American assumptions of his radicalism seem to have rested largely on his anti-Americanism. And even here there was disagreement: one Brazilian colleague commented: "I was surprised that the US had welcomed him. After all, he contested the dominant American capitalist position in the world [...]" (Vieira 2014, p. 106), but another insisted that "Guerreiro was never anti-American, as some American scholars believed. He just loved his country [...]." (Almeida, 2014, p. 71).

One big surprise was the feeling he developed for the U.S. Instead of bringing his Communist sympathies with him, his loyalty was completely to the U.S. My feeling is that he found a psychological security in the U.S. he had never known in Brazil. It wasn't so much about money, though that was a factor, as it was about intellectual freedom. Guerreiro was an independent, free spirit, and he needed the opportunity to express himself.... What he told me he valued about the U.S. was his personal freedom. He said he had never been so able to write and say what he wanted. (Sherwood, 2010, p. 123)

And Guerreiro Ramos himself repeated these same sentiments to various colleagues. At USC he was no longer, as he had been in Brazil, the embattled Bahian mulato who had grown up poor and always felt himself fighting for recognition in a very largely white academic world, fighting for employment, fighting academic battles for recognition of his intellectual positions, fighting for his political ideals. He was a respected and extremely productive scholar, with secure employment, he had a comfortable house, where he and his wife were constantly entertaining people for dinner, and he was always surrounded by admiring students: in comparative terms of the global conditions of exile, he had found a safe haven and become a "most privileged exile", able to escape the everyday concerns with asylum, livelihood, isolation (Kettler, 2011, p. 41).

Certainly it had been extremely wrenching to leave Brazil. His daughter reports that he accepted the invitation to USC "with a heavy heart" and showed deep sadness whenever he referred to leaving (Guerreiro Ramos, E. 2003, p. 5). But he had had a lot of practice in 
Brazil in confronting adversity with a confident public image. And he was a deeply practical man, as he had shown himself to be on many occasions in Brazil, when he had accepted less desirable positions than he aspired to and felt he deserved, because they were the only ones offered, and had carried them out with creativity and aplomb. He reports, for example, in his 1981 interview that when he was passed over for the position he coveted and had been recommended for as professor of sociology at the Faculdade Nacional de Filosofia in Rio, accused of supporting integralism by his rival for the job, he accepted a position as a Técnico de Administração in the Departamento de Administração e Serviço Público (DASP) (Guerreiro Ramos, 1995, p. 139-143). He was assigned to the Departamento Nacional da Criança to teach a course for medical interns on pediatrics, infant mortality and popular medicine. Certainly these were topics far from his interests, but he took this as an opportunity to conduct an empirical, survey based study of the causes of infant mortality which won critical acclaim for its innovative use of methodology and its critical stance on the use of Euro-American models of infant mortality as inappropriate for use in Brazil (Sociologia de Mortalidade Infantil, 1951).

Similarly, after his cassação, when he accepted the Ford Foundation grant to write the book on public administration in Brazil, Administração e Estratégia do Desenvolvimento: Elementos de uma Sociologia Especial da Administração (1966), he told Wilson Pizza, his student assistant and close friend, that he felt he had become a "mercenary". "I didn't want to write that book [...]. I wrote it because it was the only way to survive". But as Pizza (2014, p. 115) comments, "He also realized it was 'a rare professional opportunity". Guerreiro Ramos was a survivor, a pragmatic man who accepted adversities and made the best of them.

And it is clear that he did the same thing again in confronting his exile. His daughter comments: "My father grew to greatly admire this country, separating what the American government had done in our country from the vitality and strength of the American people" (Guerreiro Ramos, E. 2003, p. 9). He had bitterly criticized the US for its role in the 1964 coup, so the ironies of his new situation did not 
escape him or his daughter, who comments: "We came here - invited by the U.S. Government, bearing diplomatic visas. Our goal: to make what we knew would be a positive contribution to this society, even after they had destroyed ours" (Guerreiro Ramos, E. 2003, p. 9): "We came as immigrants to the very country that had participated in the destruction of our own." (Guerreiro Ramos, E. 2003, p. 6).

At USC, he remained "obsessed" with Brazil, publishing articles on Brazil in Brazilian newspapers, lecturing about it, giving talks, discussing it with friends and colleagues, claiming that "I am someone who thinks about Brazil 24 hours a day" (Azevedo, 2014, p. 89). Yet at the same time he threw himself wholeheartedly into the new situation in which he found himself in the U.S. He devoured the U.S. literature on the social sciences and public administration. A colleague recalls that

One of the things our group...was responsible for was for ordering books for the library.... When the books came in, we unpacked and shelved them for a week or two in our offices. This was to give our USC faculty a chance to keep up with the latest literature in the field. When Guerreiro found out about this, he would stop by and borrow some. I can still see him leaving our offices with 6 or 7 books strung out on his left forearm. In a discussion that I had had with him he had told me that the European writers were dominant in the field of sociology. Some weeks later he had come for his third or fourth borrowing session from our office library. As he returned the books, he went for the door, paused, turned to me, and said, "David, do you know that only Americans are writing good sociology? (Mars, 2014, p. 179)

And he participated actively in the intellectual and social life of the university, engaging in discussions and socializing with his new American colleagues and students, giving talks there, and presentations around the country at academic conferences on Sociology and Public Administration. During his sabbatical in 1972-73 he held positions as Visiting Professor at Wesleyan and Visiting Fellow in the Department of Political Science at Yale. He traveled often to Washington for long weekends to teach in the Public Affairs Center that USC's School of Public Administration had established there for American government 
personnel. USC recognized his intellectual presence, his teaching and his writing with four different awards: he won three Teaching Excellence Awards from the School of Public Administration, and two university-wide awards: a University Associates Award in recognition of his excellence in teaching, and shortly before his death, the Phi Kappa Phi Book Award for his book The New Science of Organizations (Cavalcanti et al., 2014, p. 217).

His colleagues and students found him "brilliant", "charismatic", "provocative", "inspiring", "a genius", "delightful", "fun loving", "highly social", "amazing", "charming", "engaging", though also "egotistical" and "thin-skinned". Wilson Pizza, who followed him to USC as a doctoral student, commented that "[...] other professors were very afraid of him because he had an encyclopedic mind and he would say whatever he wanted to say. He was not polite. But he was also very generous when he realized that people were interested, intelligent and had ideas of their own." (Pizza, 2014, p. 115).

His exile in the U.S. created a double commitment for Guerreiro Ramos, to the U.S. as well as to Brazil. His American colleagues emphasized his success and integration into life in the U.S., while his Brazilian colleagues emphasized his continuing passion and commitment to Brazil. With his prodigious energies he seemed able to balance both of these commitments, although after 1978 when he was free to return to Brazil, the renewed intensity of his activities there suggests that this balance was shifting.

\section{A Black Brazilian in the U.S.}

Guerreiro Ramos came to the U.S. as a Brazilian intellectual of African descent who had been deeply involved in leftist politics and racial politics. He arrived in the U.S. at a time of major racial turmoil, and California was a hotbed of this turmoil. The Civil Rights Movement and its leader, Martin Luther King, were national news, challenging racial segregation and advocating for equal rights for African-Americans. The sit-ins and the violent clashes with the police had begun in the eastern part of the country: the more radical Malcolm 
$\mathrm{X}$ had begun his career in New York and was assassinated there in 1965, followed by Martin Luther King, assassinated in 1968.

But racial violence had spread quickly throughout the country and by the early 1960s had reached California. In 1965, the year before Guerreiro Ramos arrived in California, Watts, a black ghetto with high rates of poverty and unemployment, located only a few blocks from the USC campus, was the scene of violence and rioting. After police arrested a black motorist, crowds threw rocks at the police, who called out 4000 members of the National Guard, and when it was over, there were 34 dead, 1000 injured, 3,500 arrested. Looting and arson had destroyed 1,000 white-owned businesses and caused 40 million dollars in property damages. In 1966 the Black Panthers formed in Oakland, in Northern California and formed branches throughout California cities and elsewhere in the U.S. They were viewed as the most violent of Black activists because they went armed, vowing to defend black communities against the police violence they had suffered. In 1967 the FBI launched an assassination campaign against them. Police killed Panther members in various cities and jailed the Black Panther leadership. Black Nationalism, with Malcolm X at its center, posed white and black interests as intrinsically opposed and urged racial separatism (Dawson, 2001). The Black Power Movement, which furnished the ideological backdrop for these activities from the mid 1960s to the mid 1970s, provided a loose linking of the different orientations among the groups it embraced. Broadly, it stood for racial pride, black unity and self-determination, and a central role for Black Culture. (Van Deberg, 1992, p. 5)

At USC, faculty and students were less involved in these activities than in the large public universities such as neighboring UCLA and especially Berkeley to the North, where student radicalism which had begun with the Free Speech Movement and protest against the Vietnam War merged gradually with issues of civil rights. USC was a private, elite, and very largely white institution which had cultivated an international student body and faculty, but remained relatively conservative.

Guerreiro Ramos, with his history of racial activism and concerns with racial pride and racial justice, must certainly have been deeply sympathetic to these U.S. black struggles for equality. The ideals 
espoused by the Black Power Movement in the U.S. had been close to his heart in his own work in Brazil, though he had opposed the use of violence. That he generally approved of these open confrontations with racism in the U.S. (though perhaps not with its violence) is suggested in his favorable comparisons of the open acknowledgment of racism in the U.S. with its denial and concealment in Brazil, and his own far greater racial comfort in the U.S.., even in the midst of the violence.

Yet he appears to have chosen to remain publicly detached from and largely silent about these events. I found no evidence that he spoke about, participated in, or reached out to any of these local black movements or groups. None of his many colleagues and students, Brazilian or American, in discussing Guerreiro Ramos's career at USC and his views, mentions his expressing his views on racial events in the U.S., and one American colleague, asked directly by an interviewer if Guerreiro Ramos had ever mentioned civil rights in the U.S. replies, "Not that I recall [...] I don't recall him making a mention of that, but we knew that was part of his background." (Cooper, 2014, p. 209).

The only evidence I found of Guerreiro Ramos's participation in the activities of the black community in Los Angeles during his stay in the U.S. was his participation in 1975 in a ten day event entitled "Black Brazil: A Festival of the Arts", which was held in the Inner City Cultural Center, and organized by his daughter, Eliana Guerreiro Ramos. The program for the Festival included his introduction to an exposition of Abdias do Nascimento's paintings, which celebrated Afro-Brazilian themes, and he participated with Abdias on a panel on "Brazilian Racism". The festival also included performances of Sortilégio, Abdias's best known play which dealt with "black peoples' struggle to retain their cultural values rather than become Europeanized" (Inner City Cultural Center 1975). Abdias, a fellow Brazilian exile in the U.S. living on the east coast in Buffalo, NY, was his closest friend, and someone whom he greatly admired. They had met in Rio in 1939. Abdias founded the Teatro Experimental do Negro (TEN) and the AfricanBrazilian liberation movement in Brazil in the 1940s and Guerreiro Ramos collaborated with him in supporting Afro-Brazilian arts and cultural events, advocating for racial pride, denouncing racism and challenging the myth of racial democracy (Maio, 2005). 
Abdias continued to actively pursue African diasporic activities in the U.S., promoting the African cultural heritage and supporting Black liberation activities while holding a chair in African Cultures as a professor at the U. of Buffalo. He continued to be a racial activist in his professional and personal life in the U.S., continuing his deep involvement with racial issues and the world of the African diaspora.

Guerreiro Ramos's career in the U.S. took a very different direction. Even in Brazil, by the early 1950s, he had already moved away from an identification with racial issues. As he had told his wife, Clélia, he wanted to be seen as Brazilian rather than Afro-Brazilian and was reluctant to be restricted to directly race-related issues (Ventriss; Candler, 2005, p. 357, n. 7). He had “[...] shifted his energies away from the narrow field of race relations to mainstream scholarship and became increasingly interested in organizational theory and public administration". (Ventriss; Candler, 2005, p. 350). He continued to pursue these interests in his career in the U.S. His appointment was in a school of public administration, and sociology and public administration were now at the center of his interests, his teaching, and his writing. His last book, The New Science of Organizations, made no mention of race (Candler, 2015, p. 556, n. 5).

He was the only professor of color in the Public Administration Program in a university whose professors were almost exclusively white: The whiteness of USC professors is implied by a Brazilian colleague's suggestion that Guerreiro Ramos "[...] could provide USC with a contribution from the perspective of a black man [...]" (Vieira, 2014, p. 107). This was a time in the U.S. when outside of black colleges and Black Studies or other minority programs, there were very few professors of color. It was very difficult for black scholars to be hired. Thus neither Guerreiro Ramos's areas of teaching and research, nor his situation at USC encouraged the pursuit of diasporic activities or participation in racial activism. He may have felt that connections to the Black movement would compromise his interests and opportunities as an intellectual and as a scholar. As he had remarked in his 1981 interview, he had been told that his career in Brazil had been hurt by his involvement with racial politics (Guerreiro Ramos, 1995, p. 175). 
Such involvement might even have threatened his position at USC. It seemed very secure, but it had the underlying fragility of a refugee professor from a racial minority with a reputedly radical background.

Thus, although Guerreiro Ramos was known to be very proud of his African ancestry (Bjur, 2010, p. 28), he seems to have distanced himself from the American racial scene and from his former African diasporic concerns, unlike his friend Abdias. His public silence on racial issues contrasts with his vocal opposition to the Hippie movement, also centered in California, of which he was an outspoken critic (Kirkhart, 2014, p. 195).

Another question concerns Guerreiro Ramos's racial identity in the U.S. In his 1981 interview, speaking comparatively about the U.S. and Brazil, he stated flatly that "Brazil is the most racist country in the world [...] It is paradoxical, because I don't have any problems in the U.S.. I am black and in the U.S. I am never aware of my color. On the first day of class, I sometimes say [to my students], 'As you can see, I am black.' They are shocked...no one notices". "I am "incolor", I have no color, unless I say so, and then the person exclaims, 'Porra, you really are black'. But in Brazil I am black" (Guerreiro Ramos, 1995, p. 174). In these statements he seems to be claiming that in the U.S. he is not discriminated against, his color is not an issue and is not even noticed unless he makes an issue of it himself.

Given his open acknowledgment that there is racism in the U.S., and the fact that it was an especially public matter at this time, these comments are puzzling. I believe that they may be clarified by reference to a revealing discussion his daughter Eliana had with her close friend Angela Gilliam, an African-American anthropologist, specialist in comparative race relations in Brazil and the U.S., whom she refers as "Dr. Reality". Eliana, while teaching at a college in New Jersey commented to her that "everyone likes me here", to which Gilliam responded, "You have to understand that for white academics, you are ideal. They can claim ethnic and gender integration without having to deal with a black American colleague. They see you as an exotic foreigner." (Guerreiro Ramos, E. 2003, p. 78). Again, when Eliana extolled the "integrated" multi-ethnic community she lived in 
in Greensboro NC, Gilliam responded that these were mainly "foreignborn families of color rather than African Americans" (Guerreiro Ramos, E., 2003, p. 79).

These comments highlight an important distinction between "skin color" and "racial identity", and the special discrimination reserved for African Americans in the U.S. in contrast to other groups and individuals of color living there. In Los Angeles, African Americans have been the most stigmatized of the many minority groups there (Rawls; Bean, 2003, p. 546), and this situation was certainly exacerbated at the time Guerreiro Ramos was at USC by the racial conflict and violence. Gilliam was telling Eliana that although she was "black", through her Brazilian identity she was escaping the racism directed against African Americans.

Gilliam's remarks also point to the importance of being known: in order to avoid being seen as an African American in the U.S., it is crucial that details of your personal identity be known or recognizable. Otherwise, if they are not, in an anonymous situation in a city with a substantial African American population, then you are likely to be treated, or mistreated accordingly, as an African American. Eliana, while identifying herself as a Brazilian, herself experienced racial discrimination in situations where she was not known.

Similarly, her father, Guerreiro Ramos, was known and recognized within the University as a university professor, a foreigner, or a Brazilian. Even in surroundings where he was not known, he might have been identified as a foreigner by the peculiarities of his dress, or by his heavy Brazilian accent, and exempted from the racism leveled at African Americans. At least one colleague while asserting that there was no racism on the USC campus, speculated that Guerreiro Ramos had undoubtedly experienced racial prejudice outside the university (Sherwood, 2014, p. 184). Guerreiro Ramos does not mention it. But thinking of these comments in relation to his situation, the significance of his being identified within the university setting as a Brazilian of color rather than an African American, thus avoiding the racism to which African Americans were exposed, may go some way to explaining why he claims he did not experience racial discrimination. 
And it may also be a factor in his choosing not to participate in wider racial events in the city. From accounts by his colleagues, he seems to have lived and moved largely between the university and his home, or other academic settings.

Gilliam also tells Eliana that she escapes much racism because she is seen as an "exotic foreigner". I believe that this also applies to her father who was also seen as "an exotic foreigner". Many of his American colleagues and students seem to have seen him this way, and it is an image that he himself may well have cultivated. Consider the memorable description of him by an American colleague at a dinner party in Washington while Guerreiro Ramos was on one of his trips there. It was given by an American diplomat and attended by colleagues and doctoral students. The author describes it as an "unforgettable opportunity to see and hear the mythical professor, whose stories and lectures accompanied me through the four years of my bachelor's degree at EBAPE and beyond $[\ldots]^{\prime \prime}$

Sitting in a comfortable chair, wearing Franciscan sandals, Guerreiro, just like a famous Indian Guru, spoke to the captivated students who surrounded him below, sitting cross-legged on the carpeted floor. With the common, or convenient, nonchalance of an intellectual who is detached from irrelevant matters, he let the ashes from his inseparable cigar fall onto his chest. He was protected by a white t-shirt, over which he wore a simple button-down shirt, with most of the top buttons untidily left open; all of this covered an honest belly. His Bahian figure was undeniably captivating, and it was strengthened by his critical analyses, fueled by penetrating intelligence and densely referenced originality. (Cavalcanti, 2014, p. 14)

Several other descriptions of him suggest this same guru-like image. There was even a group of followers, student interns who were known as "Guerreiro's boys" (Almeida, 2014, p. 69). I believe, then, that Guerreiro Ramos's reference to experiencing himself as "incolor" was related to the incorporation of his skin color within other, stronger identities that operated within the university setting: as a professor, a Brazilian, or even more significantly, as an "exotic foreigner". He thus escaped the brunt of American racism. 


\section{Exile and "In-Betweenness"}

After 1978, when political amnesty was declared in Brazil, Guerreiro Ramos returned there several times to set up a program in Public Administration at UFSC, and resumed his columns in Brazilian newspapers (Soares, 2005). He had said that he would never move back to Brazil, and certainly his USC colleagues thought the same. But his daughter claims that his 1979 trip to Florianópolis was undertaken as an initial step "to prepare his return" (Guerreiro Ramos, E. 2003, p. 7). His death in 1982 made the question moot. The issue of whether his exile was temporary or permanent was never resolved. Even if he had lived longer it seems likely that it still would not have been resolved. His claim in a 1979 interview in Brazil that "mentally he had never left Brazil, and now intended to spend long periods there" (Soares, 2005, p. 18) was a characteristic Guerreiro Ramos solution, which located him "in-between" the two countries.

The theme of "in-betweenness" dated from his first book of poems, O Drama de Ser Dois (1937), and the term was often applied to his racial and class situation in Brazil: "as an educated AfroBrazilian he was a rare educated black man among the largely white intelligentsia" who had risen from poverty but was "not seeking to assimilate seamlessly into the elite by adopting its values" (Ventriss; Candler, 2005, p. 349). He was in between black and white worlds, "in between these two worlds of poverty and power" (Ventriss; Candler, 2005, p. 352). His exile in the U.S. provided another venue for him to develop the sense of his own "in-betweenness", as suspended between places and identities, fitting in nowhere. He straddled two cultures, and felt that he belonged to neither. According to a colleague, he

felt a tension because here he was in the United States but he wasn't of the United States. He was raising questions that were quite foreign to the intellectual ears of a lot of Americans, yet he wanted to get their attention on the critical issues that he thought the U.S. and others would - and should - face [...] He was clear to me on the point that because of his intellectual stance on certain issues it made him difficult to be understood even with his colleagues at USC. Ramos, I felt, was more comfortable 
with others outside the U.S. context, ie Brazilians and others. So I think he always felt the tension of being somewhat intellectually homeless in a way - not finding a place where he was fully appreciated as he grappled with some of the fundamental issues that he tried to articulate in his book, The New Science of Organizations, and his other articles. (Ventriss, 2014, p. 172-173).

On his 1981 trip to Brazil, an ex-student visited him, and picking up a copy of his new book [The New science of Organizations] commented to him: "You don't belong to the American community. This book is a book written in English by a Brazilian academic" to which Guerreiro Ramos replied: "You are exactly right. I don't belong to anything. I am not an American academic [...] and this book has nothing to do with [...] it is against American social sciences. But this I owe to Brazil, because Brazil gave me this amorphousness, this shapeless character. I am not in anything, nothing, I don't belong to anything. I am me. I am wherever my interests are." (Guerreiro Ramos, 1995, p. 159).

Brazil had given him the "amorphousness" to resist identification with particular social categories and places; his exile in the U.S. provided him with new perspectives, a sharper vision, greater analytic perception (Guerreiro Ramos, 1995, p. 175). It helped him to enhance his sense of liminality, of outsiderness, the stance of the "parenthetical man" that he felt was necessary for good social science or public administration: the detachment that favored and was necessary for critical judgment. Living in the U.S. helped him to realize this analytical ideal, to achieve the position of the analyst who gains critical vision to reflect on situations without personal bias". "The parenthetical man is one who examines social life as a spectator, seeking to refrain from judgments, standing aside from internal and external circumstances in order to better understand his social environment [...]" (Almeida, 2014, p. 77-78). The experience of exile in magnifying Guerreiro Ramos's outsiderness helped him to turn it into a more powerful analytic tool. But it was a stance created during his exile, and a product of it, and might have been much harder to maintain once he was able to return to his native country.

His exile had hurt his academic and intellectual career. In the U.S., while he had great success at USC, it was a largely local success 
that never translated into national prominence, though he lectured at universities and at conferences around the country. His erudition, and his European theoretical orientation in the social sciences were mostly lost on his American audience, especially given the complexity and density of his writing. His final book, The New Science of Organizations, published in English in 1981 (U. Toronto Press), which he considered to be his greatest achievement, received very mixed reviews. And returning to Brazil, he discovered that his years of exile had damaged his status there. After 13 years away, except for old colleagues and his many students, his work was largely ignored in the field of sociology, which he always considered his primary intellectual home. Florestan Fernandes, the other major figure in the field of sociology at the time of Guerreiro Ramos's exile and also exiled after the coup, was not forgotten, because his colleagues at USP, Brazil's leading school of sociology, "wouldn't let that happen". These same colleagues, because they were opposed to and highly critical of Guerreiro Ramos's sociological methods and ideas, may even have contributed to his obscurity (Azevedo, 2014, p. 86). Guerreiro Ramos's return to Brazil renewed interest in his work and generated many events honoring his career and his intellectual achievements, and new publications and republications of his books. Hopefully these will restore his place in Brazilian intellectual history and draw social scientists to the originality and importance of his thought.

\section{Acknowledgments}

I would first like to thank Ilka Boaventura Leite for her work in organizing the conference on which this volume is based and inviting me to participate. Jane Dougall, Research Librarian at the Bard College Library, worked tirelessly and uncovered much valuable information. Profs. Myra Armstead and Tabetha Ewing, colleagues at Bard, helped me with references to the racial protests in California during the period Guerreiro Ramos was there. Maria Amelia Schmidt Dickie helped with translations, and Mario Bick provided advice, sources and companionship during the process of writing. 


\section{References}

ALMEIDA, Adilson de. Interview. In: CAVALCANTI, B. et al. (Ed.).

Guerreiro Ramos: Coletânea de Depoimentos/Collection of Testimonials. Rio de Janeiro: Editora FGV, 2014. p. 68-79.

AZEVEDO, Ariston. Interview. In: CAVALCANTI, B. et al. (Ed.). Guerreiro Ramos: Coletânea de Depoimentos/Collection of Testimonials. Rio de Janeiro: Editora FGV, 2014. p.80-91.

BJUR, Wesley. Personal Memories. In: CLAYTON, Ross et al. (Ed.). Futures of the Past: Collected Papers in Celebration of its More Than 80 Years: University of Southern California's School of Policy; Planning and Development; iUniverse, 2010.

CANDLER, Gaylord George. Assimilação crítica and research on the periphery. Cadernos EBAPE, [S.l.], v. 13, número especial, p. 560-572, 2015.

CAVALCANTI, B. et al. (Ed.). Guerreiro Ramos: Coletânea de Depoimentos/Collection of Testimonials. Rio de Janeiro: Editora FGV, 2014. CAVALCANTI, Bianor. Introduction. In: CAVALCANTI, B. et al. (Ed.). Guerreiro Ramos: Coletânea de Depoimentos/Collection of Testimonials. Rio de Janeiro: Editora FGV, 2014. p. 12-16.

CLAYTON, Ross et al. Futures of the Past: Collected Papers in Celebration of its More Than 80 Years: University of Southern California's School of Policy; Planning and Development; iUniverse, 2010.

COOPER, Terry. Interview. In: CAVALCANTI, B. et al. (Ed.). Guerreiro Ramos: Coletânea de Depoimentos/Collection of Testimonials. Rio de Janeiro: Editora FGV, 2014. p. 207-215.

DAWSON, Michael C. Black Visions: the Roots of Contemporary AfricanAmerican Political Ideologies. Chicago: University of Chicago Press, 2001.

GILLIAM, Angela. Introduction. In: The Road from Rio: Immigrant Essays, by Eliana Guerreiro Ramos. Tucson AZ: Hats Off Books, 2003. p. 3-7.

GUERREIRO RAMOS, Alberto. Entrevista com Guerreiro Ramos.

A Sociologia do Guerreiro. Ed. By Lucia Lippi Oliveira. Rio de Janeiro: Editora UFRJ, 1995. p. 131-183.

GUERREIRO RAMOS, Eliana. The Road from Rio: Immigrant Essays. Tucson AZ: Hats Off Books, 2003.

INNER City Cultural Center. Catalogue for Black Brazil: a Festival of the Arts. Los Angeles, CA, 1975. 
KETTLER, David. The Study of Intellectual Exile: a paradigm. In Liquidation of Exile: Studies in the Intellectual Emigration of the 1930s. London: Anthem, 2011. p. 1-23.

MAIO, Marcos Chor. Cor, intelectuais e nação na sociologia de Guerreiro Ramos. O Centenário de Guerreiro Ramos. Cadernos EBAPE.BR, [S.l.], v. 13, número especial, p. 605-630, 2015.

MARS, David. Interview. In: CAVALCANTI, B. et al. (Ed.). Guerreiro Ramos: Coletânea de Depoimentos/Collection of Testimonials. Rio de Janeiro: Editora FGV, 2014. p. 178-179.

NELSON, Kim. Introduction to the Book. In: CLAYTON, Ross et al. (Ed.). Futures of the Past: Collected Papers in Celebration of its More Than 80 Years: University of Southern California's School of Policy, Planning and Development; iUniverse, 2010. p. 11-24. .

OLIVEIRA, Lucia Lippi. A Sociologia do Guerreiro Ramos. Rio de Janeiro: UFRJ, 1995.

PIZZA, Wilson Junior. Interview. In: CAVALCANTI, B. et al. (Ed.).

Guerreiro Ramos: Coletânea de Depoimentos/Collection of Testimonials. Rio de Janeiro: Editora FGV, 2014. p. 109-116.

SAMPLE, Steven B. The University of Southern California at 125: Inventing the Future Since 1880. Exton PA: The Newcomen Society of the United States. University of Southern California, 2005.

RAWLS, James; WALTON, Bean. California: An Interpretive History. $8^{\text {th }}$ Edition. New York: McGraw Hill, 2003.

SOARES, Luiz Antonio Alves. Guerreiro Ramos: considerações críticas a respeito da sociedade centrada no mercado. Rio de Janeiro: Conselho Regional de Administração do RJ, 2005.

SHERWOOD, Frank. Biography of Alberto Guerreiro Ramos. In: CLAYTON, Ross et al. Futures of the Past: Collected Papers in Celibration of its More than 80 Years: University of Southern California's School of Policy, Planning, and Development; iUniverse, 2010. p. 119-125.

VAN DEBERG, William L. New Day in Babylon: the Black Power movement and American Culture 1965-1975. Chicago: University of Chicago Press, 1992.

VENTRISS, Curtis, Interview. In: CAVALCANTI, B. et al. (Ed). Guerreiro Ramos: Coletânea de Depoimentos/Collection of Testimonials. Rio de Janeiro: Editora FGV, 2014. p. 171-177. 
VENTRISS, Curtis; CANDLER, G. G. Alberto Guerreiro Ramos, 20 Years Later: A New Science Still Unrealized in an Era of Public Cynicism and Theoretical Ambivalence. Public Administration Review, [S.l.], v. 65, n. 3, p. 347-359, 2005.

VIEIRA, Paulo Reis. Interview. In: CAVALCANTI, B. et al. (Ed.). Guerreiro Ramos: Coletânea de Depoimentos/Collection of Testimonials. Rio de Janeiro: Editora FGV, 2014. p. 105-108.

Recebido em 19/04/2016

Aceito em 20/04/2016 